\section{MIDDLE ATLANTIC COMMUNITY COLLEGE LIBRARIANS}

A meeting of librarians from selected community colleges in the Middle Atlantic area was held on Dec. 9 at the Community College of Philadelphia. J. L. Gotlobe, librarian of Philadelphia's year-old Community College, and Guy D. Chappell, assistant librarian, initiated the librarians meeting and served as co-hosts for the afternoon conference. The meeting enabled librarians of similar institutions from Pennsylvania, Maryland, and New Jersey to come together and discuss problems of mutual and individual concern and provided assistance to those community colleges just getting underway. Among the numerous topics discussed were preparation for accreditation, AV materials in the library, availability and use of published lists for assembling a basic community college collection. During the informal round table discussion the remarks of Mrs. Katherine Brubeck of Baltimore Junior College and James McCoy of Trenton Junior College were especially helpful.

Mr. Gotlobe closed the meeting, stating he hoped the groundwork laid at this brief conference would prompt future meetings to discuss the many other development phases of academic libraries and services which are unique to community colleges.

\section{SE MEDICAL LIBRARIES}

On Wednesday, October 5, 1966, the deans, administrative officers, and medical librarians of eight medical schools in Alabama, Georgia, Kentucky, Mississippi and Tennessee met at the Vanderbilt medical center to discuss the regional medical library concept and its implementation. Dr. Carl D. Douglass, chief of facilities and resources division of the National Library of Medicine, and Dr. Louis S. Gerber, regional medical library program director, $\mathrm{Na}$ tional Library of Medicine, were on hand to discuss viewpoints and philosophy related to this program, including basic criteria for the designation of medical libraries as Regional Medical Library Centers, the ideal concept of the regional medical library complex, the cooperation of several institutions for the development of extensive resources, MEDLARS search centers, the training of medical librarians, and information services.

ACRL Membership, December 31, 1966 11,464 December 31, 1965 10,126

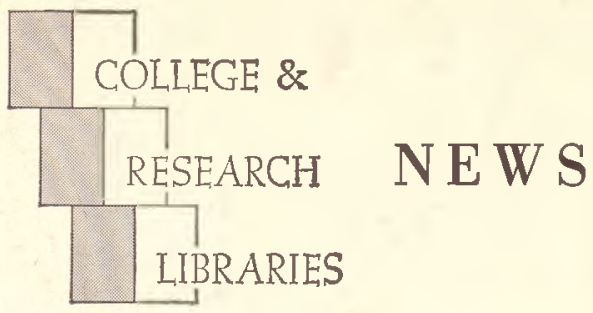

ACRL News Issue of College \& Research Libraries

Editor, David Kaser, Joint University Libraries, Nashville, Tenn. 37203.

Publications Officer, Mary Falvey, 50 E. Huron St., Chicago 60611.

ACRL Executive Secretary, George M. Bailey.

ACRL Officers, 1966/67: President, Ralph E. McCoy; College Libraries Section Chairman, Lee Sutton; Junior College Libraries Section, Harriett Genung; Rare Books Section, William H. Runge; Subject Specialists Section, Mary E. Schell; Agriculture and Biological Sciences Subsection Chairman, Roy L. Kidman; Art Subsection, Mrs. Kathryn Blackwell; Law and Political Science Subsection, Jane Wilson; Slavic and East European Subsection, Bohdan S. Wynar; University Libraries Section Chairman, John M. Dawson.

Editorial Board: Johs M. DAwson, University of Delaware; Gustave A. Harrer, Boston University; SaMUEL Rothsten, University of British Columbia; JAMES E. SKIPPER, Association of Research Libraries; Norman E. Tanis, Kansas State College of Pittsburg; MaUrice F. TaUber, Columbia University; EIfEen Thornton, Oberlin College.

News from the Field, Personnel profiles and notes, classified advertising, official matter of ACRL, and other material of a timely nature is published in the News issues of College \& Research Libraries.

Inclusion of an article or advertisement in $C R L$ does not constitute official endorsement by ACRL or ALA.

Production and Advertising and Circulation office: 50 E. Huron St. Chicago, Ill. 60611. Change of address and orders for subscriptions should be addressed to College o Research Libraries, for receipt at the above address, at least two months before the publication date of the effective issue.

Subscription to $C R L$ is included in membership dues to $A C R L$ of $\$ 6$ or more; other subscriptions to $C R L$ are $\$ 5$ per year. Subscriptions do not include News issues; memberships do not include miscellaneous unscheduled supplements, which are available by purchase only. Retroactive subscriptions are not accepted. Single copies of $C R L$ are available at $\$ 1.25$ from ALA Publishing Department.

Indexed in Library Literature. Abstracted in Library Science Abstracts. Book reviews indexed in Book Review Index.

College \& Research Libraries, is the official joumal of the Association of College and Research Libraries, a division of the American Library Association; and is published seventeen times per year-bi-monthly as a technical journal with II monthly News issues, combining July-August-at 1201-05 Bluff St., Fulton, Mo. 65251 .

Second-class postage paid at Fulton, Mo, and at additional mailing offices. 